\title{
Perceptions of and responses to coastal erosion risks: The case of Cotonou in Benin
}

\author{
Florence de Longueville ${ }^{\mathrm{a}, *}$, Yvon-Carmen Hountondji ${ }^{\mathrm{b}}$, Liliane Assogba ${ }^{\mathrm{c}}$, Sabine Henry ${ }^{\mathrm{a}}$, \\ Pierre Ozer ${ }^{\mathrm{c}, \mathrm{d}}$

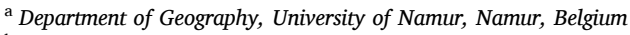 \\ b Department of Natural Resources Management, Faculty of Agronomy, University of Parakou, Parakou, Benin \\ ${ }^{\mathrm{c}}$ Department of Environmental Sciences and Management, University of Liege, Arlon, Belgium \\ ${ }^{\mathrm{d}}$ The Hugo Observatory, Department of Geography, University of Liege, Liège, Belgium
}

\section{A R T I C L E I N F O}

\section{Keywords:}

At-risk population

Coastal erosion

Vulnerability

Management

Perception

\begin{abstract}
A B S T R A C T
Intensive erosion has affected the coastal zone of Cotonou for several decades. An analysis of satellite images showed an average coastline retreat of $115 \mathrm{~m}$ in the study area over the period 2002-2013 with several hundred houses destroyed. Since 2014, a stabilisation of the coastline is observed. This study aimed at identifying the atrisk population and at analysing the perceptions of people who experience and those who manage coastal erosion risk, as well as the responses adopted. Based on four criteria and their hierarchy, we identified five profiles of inhabitants in this risk zone. (1) Wealthy people who leave the zone when they are affected or (2) fall into the category of people in danger in case they cannot migrate. (3) Fishermen who deliberately stay near the sea. (4) The most precarious people, trapped in the risk zone. Finally, (5) poor newcomers who continually increase the at-risk population. With the recent stabilisation of the coastline, the national authorities manage the "hazard" component of the risk. However, the majority of the population is not serene. The anthropogenic stress linked to evictions gradually replaced the stress to be engulfed by the sea. We conclude that the "vulnerability" component of the risk is not yet resolved. All categories of the population in this sensitive area need to be secured. Cooperation among multiple levels of governance, the application of land use planning regulations and of the Kampala Convention and the involvement of local communities are all measures which will enable to meet this objective.
\end{abstract}

\section{Introduction}

Coastal erosion is defined as the invasion of land by the sea, or as the tendency of the coastline to retreat, generating significant loss of beaches, land and ecosystems that are used for human activities [1]. Sea level rise can trigger coastal and riverbank erosion, flooding and saltwater intrusion into lakes [2-4]. Moreover, waves that break closer to the shore cause beach erosion in discrete time steps in the form of storms $[5,6]$. Human influence in the coastal area has been generally identified as a major cause of shoreline morphological change, which ultimately drives coastal erosion $[7,8]$. In the future, this type of erosion will very likely be amplified by sea level rise, changes in wave conditions and more frequent storms as consequences of global warming [3,8-12]. Amongst the coastal areas that are particularly at risk of climate change, those located on the Gulf of Guinea in West Africa rank very high [13, 14]. According to Touré et al. [15]; the West African coasts are undergoing a significant erosive process, which can be impressive in some places with average retreats exceeding $10 \mathrm{~m}$ per year. The city of Cotonou, the economic capital of Benin, is built on alluvial sand with a maximum thickness of $4 \mathrm{~m}$ [4] between Lake Nokoue in the North and the Gulf of Benin ${ }^{1}$ in the South (Fig. 1). In the east of the harbour, the coastline of Cotonou retreated by 400 m between 1963 and 1997 according to Codjia [16]. Based on a detailed analysis of remote sensing data and verified ground truth, Kaki et al. [17] observed a coastal erosion of nearly $500 \mathrm{~m}$ between 1963 and 2005 in the same area. In this case, the coastal erosion is mainly due to (i) the obstruction of the littoral transit by the deep-water harbour and its pier built in the early 1960s, (ii) the decreasing transport of river sediments from the upstream

\footnotetext{
* Corresponding author. Department of Geography, University of Namur, Rue de Bruxelles 61, 5000, Namur, Belgium.

E-mail addresses: florence.delongueville@unamur.be (F. de Longueville), yvon.hountondji@gmail.com (Y.-C. Hountondji), aslili1@yahoo.fr (L. Assogba), sabine. henry@unamur.be (S. Henry), pozer@uliege.be (P. Ozer).

1 It is one part of the Gulf of Guinea.
} 
catchment (Mono River) since the construction of the Nangbéto Dam in 1987, and (iii) the decrease in sedimentary inputs from the West because of diverse coastal protection structures [18-20]. Moreover, activities of sand quarries and beach sand mining $[17,21]$ have amplified the phenomenon in Benin, as in Ghana [22-24].

Defined as the potential of a given area to be harmed by the impact of erosion and quantified by comparing the intensity of the impact with the adaptability of the system [25], the vulnerability to coastal erosion is particularly high in West Africa. The Gambia, Ghana, Togo, and Benin and Nigeria have the most vulnerable coastal communities with people suffering tremendous economic losses, destruction of homes, livelihoods and cultural artefacts [26]. Urbanisation in African cities is shaped by the combination of past and current governmental planning practices, traditional land ownership systems, private development interests, direct foreign investments, and migration. The interaction of these drivers creates hazard-prone areas in settlements facing an increase in the risk of natural disasters [27]. Coastal erosion and sea flooding are serious problems that affect the safety and livelihoods of many dwellers along the West African coast [28]. As in other parts of the world, the coast of the Gulf of Guinea concentrates the biggest cities of the region and a large proportion of the population $[29,30])$. Coastal areas, characterised by high-density populations [31,32] are growing rapidly, notably because of rural-urban migration inflows [20,33]. Worldwide, a large proportion of urban expansion is taking place as informal settlements in areas exposed to environmental hazards (low-lying places, coastal areas ...) $[34,35]$. The rapid increase in coastal populations imposes more pressure on coastal lands through alteration of natural habitats and leads to increased erosion [7,36]. People living in these coastal areas that lack basic infrastructure and services are dispropor- level rise is expected to cause most migration in the next decades [42]. According to Appeaning Addo [7]; various studies have quantified the rate of landward change with regard to the position of the coastline but not much work has been done to estimate the rate at which human settlements are moving closer to the coastline. In addition, there is a large research gap regarding the responses of households, communities, and states towards coastal erosion and sea level rise [43].

The main objectives of this study are to identify populations living in a coastal area of Cotonou affected by rapid erosion for several decades and to analyse the perceptions of and responses to risks by those who experience the risks and those who manage the risks.

\subsection{Study area}

The study area comprises $8 \mathrm{~km}$ along the sea (Gulf of Benin) to the east of the Siafato groyne ${ }^{2}$ built in 1962-1963 just after the harbour (Fig. 1). This zone has been significantly eroded since the early 1960s. Prior to this, the coastline was linear. In 2013, seven groynes, one at every kilometer from the Siafato groyne, have been implanted along the coast as coastal protection measures (see Fig. 1, below, Groyne 1 to Groyne 7) and two additional intermediate groynes (the first one between Groyne 1 and Groyne 2 and the second one between Groyne 6 and Groyne 7) have recently been integrated (April 2018). As shown in Fig. 1, the series of groynes have been constructed up to the administrative limit of the municipality of Cotonou, neighboured by the municipality of Sèmè-Podji. The study area is also characterised by highdensity housing to the limits of the beach. As shelter types, we find standing houses, permanent houses, makeshift houses and some plots of land free of any construction. While some zones of the coastal area are
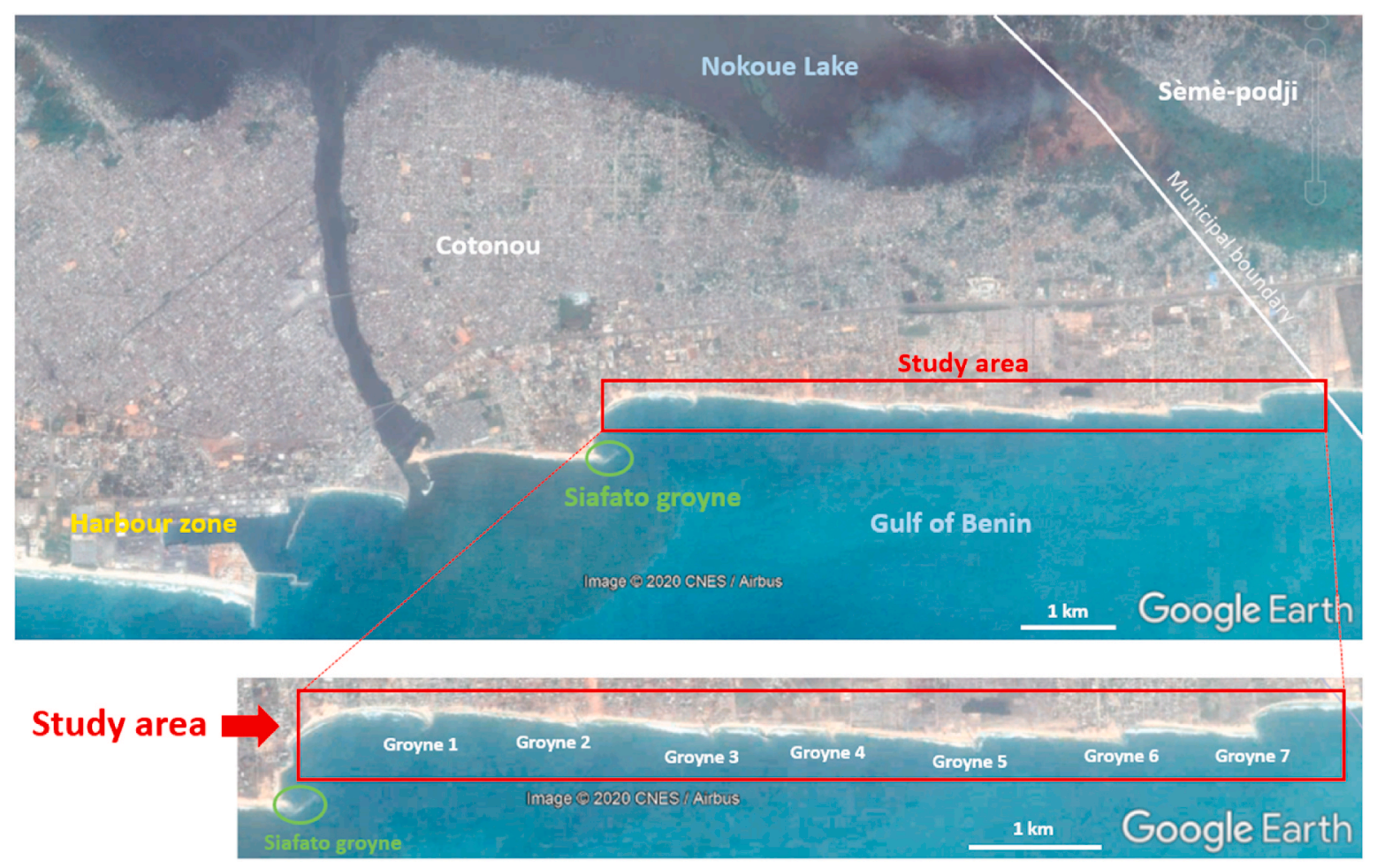

Fig. 1. Location of (top) and zoom on (down) the study area on a satellite image recorded on December $08,2015$.

tionately affected by the impacts of climate change [37,38]. Moreover, both, rapid demographic growth and inadequate resources for urban development exacerbate their vulnerability. Actually, population growth in coastal areas places more people potentially at risk from natural hazards, which could mean that post-disaster displacement and migration from coastal areas will increase in the future [39-41]. Sea

\footnotetext{
${ }^{2}$ Groynes are long, narrow structures constructed from timber, sheet piling, concrete or boulders perpendicular or slightly oblique to the shoreline. They are designed to reduce along-shore currents and littoral drift, and to retain the beach sand [72].
} 
more endowed with permanent houses and other zones are more dedicated to temporary housing, we mainly observe a mix of these dwellings, especially closer to the coastline. Whether it is due to the construction of the groynes (storage of materials) or sanitation of the area, the authorities have regularly forced demolition of makeshift shelter and eviction of the inhabitants.

\section{Methodology}

We used the triangulation method to obtain data and adopted a multidisciplinary approach to analyse the social and management problems posed by coastal erosion. The triangulation method allows the acquisition of data from various angles, while taking into account the scale of the research study [26]. The multidisciplinary approach focuses primarily on the different disciplines and the diverse perspectives they bring to understand an issue. In practice, to meet our objectives, we proceeded in an estimation of the progression of coastal erosion in the study area based on satellite images available in Google Earth and in a long term study of risk perception and responses based on data from two fieldwork trips (semi-structured interviews with residents and stakeholders in July 2014, and questionnaires with residents and semi-structured interviews with stakeholders in May 2018).

\section{* Step 1 - Assessing the changes in the study area}

We used a set of recent very high-resolution satellite images recorded from 2002 up to 2018. Multi-temporal analyses have been carried out in a Geographical Information System (GIS) to assess the coastline retreat between 2002 and 2018 and to observe the dynamic of human settlements in the risk zone during the same time period. Concretely, we compared some couples of images in order to estimate, by photointerpretation, the land lost to the sea between date pairs and to count the houses engulfed or destroyed by the encroachment of the sea in a first time and the new houses built in the risk zone in a second time. Based on the average household sizes published by the "Institut National de la Statistique et de l'Analyse Économique" (INSAE), we then assessed the number of people affected by house destruction and the number of people moving in a new house, including makeshift houses. According to the fact that important protection measures of the coast (seven groynes) have been implemented in 2013, we have defined two main reference study periods: 2002-2013 and 2014-2018. Images recorded in 2002, 2013, 2014 and 2018 were primarily analysed but we also used other images (notably 2004, 2011, 2015) to obtain information about intermediate situations. We complemented this analysis with on-site observations and photographs taken during several fieldwork trips conducted in November 2012, September 2013, July 2014, February 2015 and May 2018.

\section{* Step 2 - Identifying the populations in the study area}

In July 2014, a few months after the completion of the coastal protection measures, we collected testimonies from 20 residents located within a maximal distance of $150 \mathrm{~m}$ of the coastline in the risk area. These respondents were chosen randomly along the beach in the study area, however there was an effort to choose residents of different shelter types (standing house, permanent house, makeshift house). They were asked to tell their story in the local language (Fongbe). We recorded, in a notebook and with the help of an interpreter (Fongbe-French), evidence relating to their origin, their movement(s) and those of their relatives and past/current neighbours, their activities, their perception of risks, their fears and their strategies to protect themselves against impacts of erosion. Based on direct data (relating to respondents) and indirect data (relating to the parents/relatives/neighbours of the respondents), we carried out a typology of populations in the study area using four criteria of differentiation of residents (house with a permanent structure, standing house, activity and long-time residents) organised following a dichotomic tree. After that, we analysed how respondents perceived risk and which strategies they implemented. * Step 3 - Determining the risk perception and the responses of
inhabitants

In May 2018, five years after the completion of the coastal protection measures, we carried out a questionnaire survey with about thirty close questions and a few open questions among 37 individuals settled within a maximal distance of $150 \mathrm{~m}$ of the coastline in the study area. These respondents were approached by chance but they were chosen based on a maximum possible spatial distribution in the study area. The purpose was to collect respondents' perceptions of the dynamics of the coastline, the effectiveness of protection structures and coastal development policies. Collected data have been encoded in a spreadsheet. By combining these data with data obtained by testimonies in July 2014, we analysed how inhabitants of the study area perceived risk and which strategies they implemented in response to risk in five periods of time corresponding to the timeline of the construction of the seven groynes to protect the zone (before 2013, in 2013, a few months after, five years after, and in the future).

\section{* Step 4 - Analysing the risk perception of stakeholders}

In 2014, we conducted eight semi-structured interviews with stakeholders engaged in coastal protection (representatives of the local authorities (2), regional authorities (1), national authorities (1), national agency (1), residents' association (1) + actors implicated in reduction of climate change impacts (2)) about their opinion as regards the efficiency of structural measures. We also had discussion on the matter with Beninese researchers working in the field of environment, geology, hydrology and law. In 2018, we interviewed seven persons among stakeholders engaged in coastal protection (representatives of the local authorities (2), regional authorities (1), national authorities (1), residents' association (1) + civil engineer (1) and actor engaged in coastal management (1)) about their perceptions of the dynamics of the coastline, the effectiveness of protection structures, current coastal development policies and future prospects. Thanks to interview transcription, it was possible to highlight keywords and make connections between answers. Analyses of the answers allowed us to understand the risk perception of authorities and stakeholders just after and five years after the completion of the coastal protection measures. All of these respondents remain anonymous in this paper.

\section{Results}

\subsection{Changes in the study area}

\subsubsection{From 2002 to the installation of seven groynes in 2013}

Between 2002 and 2013, we measured a generalised coastline retreat in the study area of about $115 \mathrm{~m}$ with local variations from 38 to $145 \mathrm{~m}$ (Fig. 2). On these estimations of coastline regression measurement, we considered $5 \mathrm{~m}$ as a margin of error that may arise from natural influences on the position of the coastline (winds, tides), imprecisions related to the images (ortho-rectification, mosaic) and measurement uncertainties (digitalisation and photo-interpretation). Our estimations are consistent with results published by Codjia [16] and Kaki [17] for previous periods. It corresponds to an erosion rate of on average $10.5 \mathrm{~m}$ per year, which is well above the rate considered as high by Frick-Trzebitzky and colleagues [27] that cited the example of a loss of $1 \mathrm{~m}$ per year measured between 2005 and 2011 in Glefe (Ghana) by Amoani et al. [22].

This period is also characterised by the implementation of measures to reduce erosion by the authorities. Under the pressure of some local and regional associations for the protection of the environment, all marine sand quarries were closed in March 2009 (Decree No. 2008-615 

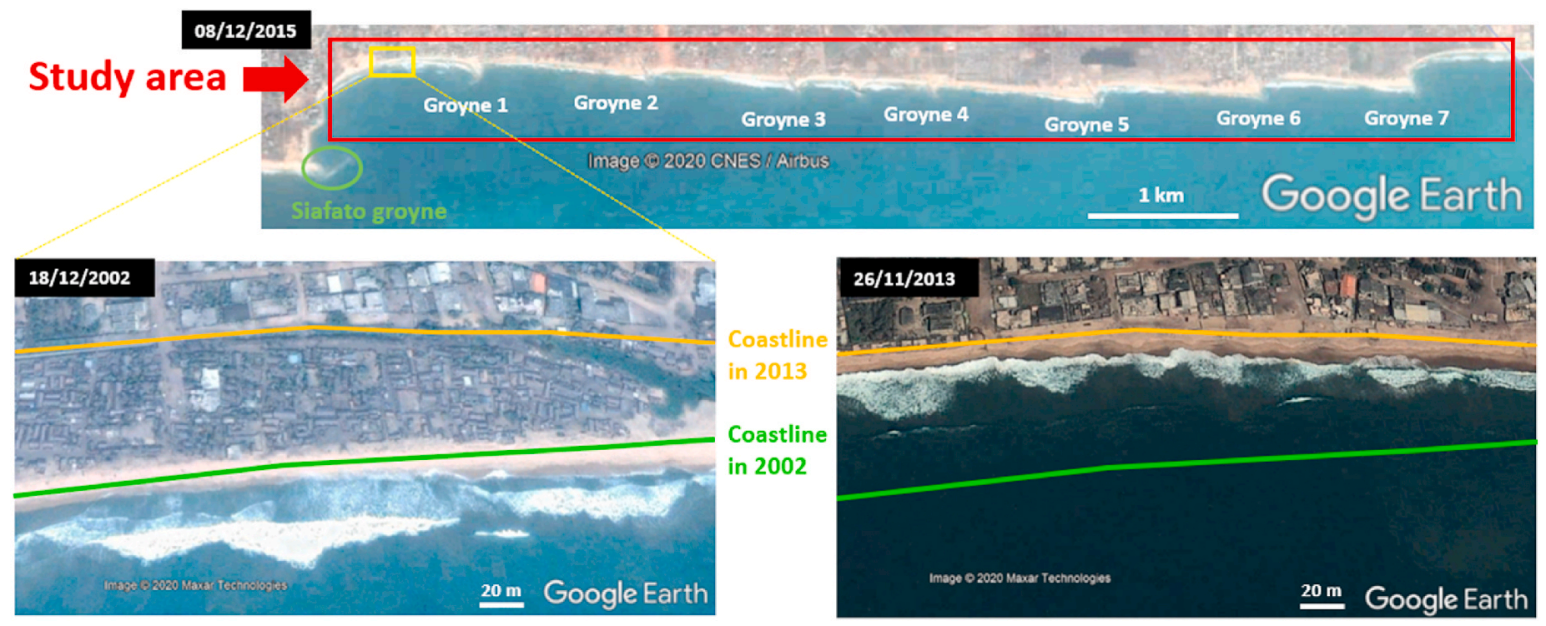

Fig. 2. Evolution of the coastline in the Western part of the study area between 2002 and 2013.

of October 22, 2008). The exploitation of lagoon sand has replaced the exploitation of marine sand. This was a positive but not sufficient measure to stop the erosion that we still observed during the next years. Following the national strategy to implement the UN Framework Convention on Climate Change, Benin proposed two adaptive options: the relocation of economic activities, communication networks, hotel infrastructures and communities and the stabilisation of the coastline by groynes [44]. In 2013, seven groynes, one every kilometer, were built in the east of the Siafato groyne in the most exposed and densely occupied zone (our study area).

The loss of land to the sea (nearly 93 ha in the study area from 2002 to 2013) had major impacts on human settlements. By photointerpretation, we estimated that about 800 houses disappeared because of the encroachment of the sea. This corresponds to 60 standing houses spread over 104 enclosed parcels and about 750 makeshift houses (informal settlements) (see Fig. 2 for the Western part of the study area, especially concerned by loss of makeshifts houses). Considering the average household size ${ }^{3}$ of 3.9 persons [45], this means that at least 3100 individuals were likely to be affected by coastal erosion and forced to leave their homes during this period. The destruction of the standing houses is often progressive (Fig. 3, top) while makeshift houses may be destroyed by the sea within a few hours during a storm event (Fig. 3, down). In addition, authorities had proceeded with the demolition of makeshift houses and the eviction of their residents. For instance, in 2009, such destruction by authorities concerned 115 additional makeshift houses, which corresponds to about 450 additional individuals. The use of intermediate satellite images - in this case, recorded in 2011 - allowed to observe a replacement of standing houses by makeshift houses between 2002 and 2011, followed by rapid destruction of a number of these new makeshift houses between 2011 and 2013. Therefore, we can conclude that the number of destroyed makeshift houses over this $2002-2013$ period is largely underestimated.

\subsubsection{From 2014 to 2018}

Since 2014, we observed a general stabilisation of the coastline in the study area corresponding to the protected zone by seven groynes installed in 2013. This is consistent with recent measurements made by Makponse and Hounsou [46]. Very local variations have been observed at the scale of a groyne with a positive effect (accretion) on the west side and a negative effect (fast erosion) on the east side. In addition, significant erosion is visible in the eastern part of the study area in the neighbouring municipality of Cotonou, Sèmè-Podji (Fig. 4). For the next kilometres east of the protected area, a coastal erosion rate of $49 \mathrm{~m}$ per year has been calculated for the 2014-2018 period. It is frequent that measures to protect coasts induce unwanted effects - caused by littoral drift - on adjacent beaches $[47,48]$.

The installation of protection infrastructures also leads to some consequences in terms of human settlements: it restores confidence in the safety of the area of landowners and investors who are starting to build new standing houses and resorts in the now protected zone and new blocks of buildings and housing are currently under construction. By photo-interpretation, we observed the recent establishment of 2 standing houses and 3 large buildings in the study area. In addition, the gradual accumulation of sediment between groynes increases the feeling of safety in population. From the Siafato groyne to the groyne 1, we counted 78 new makeshift houses in enclosed parcels. Between the groyne 2 and the end of the study area, there are 37 new makeshift houses. Recent official figures give 4.2 persons as the average household size in this zone of Cotonou [49]. Therefore, as a result of the relative stabilisation of the coastline, at least 480 people settled very close to the sea in the risk zone, their safety depending for the most part on the effectiveness of the protection structures. Inversely, some disappearances of makeshift houses and informal settlements, specifically of these located outside enclosed parcels in the study area, have been observed on the most recent satellites images. This appears as evidence for a will to "cleanse" the coastal area (i.e. through demolitions of makeshift shelters and evictions of their residents) to give way to a tourism-related development and allow the coast gentrification [50], now that coastline seems stabilised.

\subsection{Who are the people who settle in this risk zone and how do they respond to erosion risks?}

Testimonies of respondents recorded during the fieldwork in July 2014 and further elaboration based on the four criteria of differentiation of residents (house with a permanent structure, standing house, activity and long-time residents) have led to five typical profiles of people present in the study area: wealthy people, people in danger, fishermen, precarious people and poor newcomers (Fig. 5).

Analyses of respondents' stories allowed us to identify their own movements ("direct") and those of their relatives/neighbours ("indirect"). Obviously, movements inside the risk zone and from the risk zone to other places may represent a response to risks. We also observed that people belonging in the same category presented similarities in terms of origin and trajectories (Fig. 7).

\footnotetext{
${ }^{3}$ For the department of Littoral-Cotonou.
} 

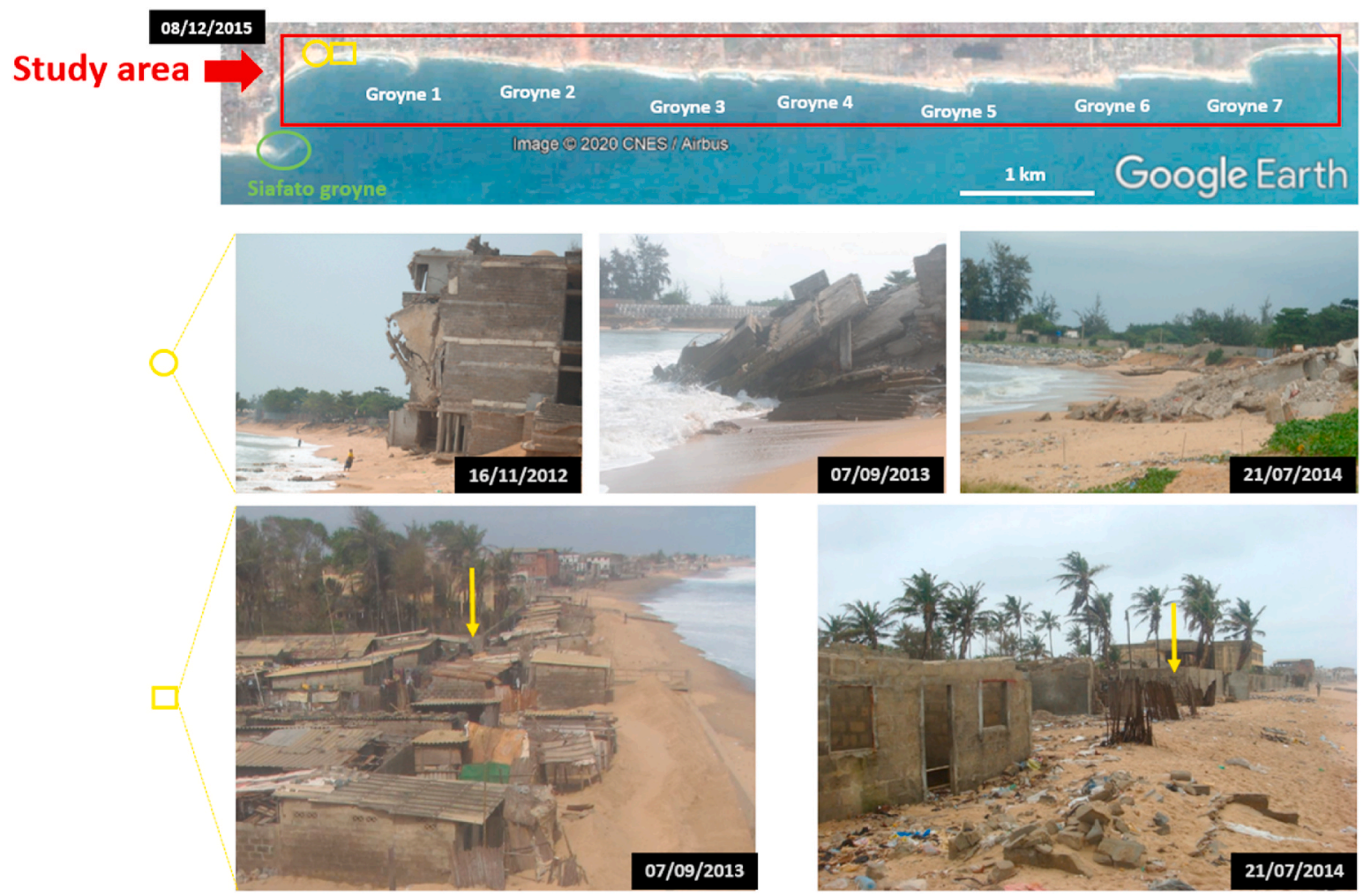

Fig. 3. Progressive destruction of standing houses (top) and rapid destruction of makeshift houses (down) (Photos: P. Ozer and F. de Longueville).
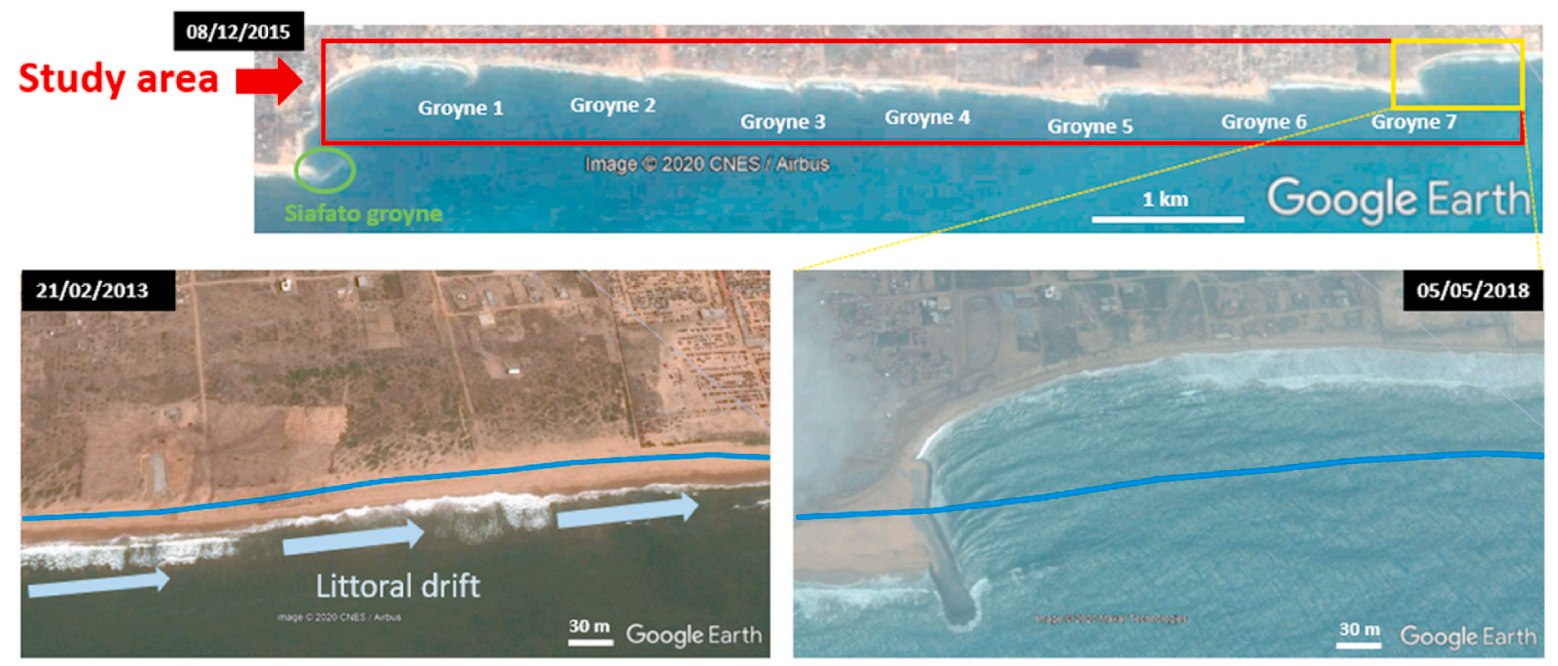

Fig. 4. Rapid erosion in the east of the protected zone.

- Wealthy people (green in Fig. 7) [0 direct, dozen by 8 indirect, several dozen by local authorities ${ }^{4}$ ]: they live inside standing houses located in the coastal area. If their houses are threatened by the sea, they leave the risk zone thanks to their financial and social capital. According to evidence, when they move they relocate inland, usually to the peripheral areas of Cotonou (Calavi, Sèmè-Podji ...) or beyond (Porto Novo). This information was provided indirectly by people that lived in the ruins of destroyed houses. A man told us: "Nous

\footnotetext{
${ }^{4}$ Read: "there were 0 wealthy people among our respondents, dozens of wealthy people have been evoked by 8 of our respondents and local authorities evoked several dozens of wealthy people".
}

habitons actuellement contre la clôture de plusieurs maisons en dur qui ont été détruites par la mer. Les propriétaires de ces maisons sont partis vivre chez des parents à eux. » ["We currently live against the fence of several houses with a permanent structure that have been destroyed by the sea. The owners of these houses went to live with their parents."]. A fisherman said: « Ma famille est établie ici avec d'autres familles de pêcheurs. C'est la parcelle d'un proche qui était propriétaire de la maison effondrée, il est parti vivre à Calavi. » ["My family is here with other fishing families. This is the parcel of a relative who was the owner of the collapsed house, he went to live in Calavi."]

- People in danger (purple in Fig. 7) [3 direct, dozen by 2 indirect, several dozen by local authorities]: they have an ownership title and 


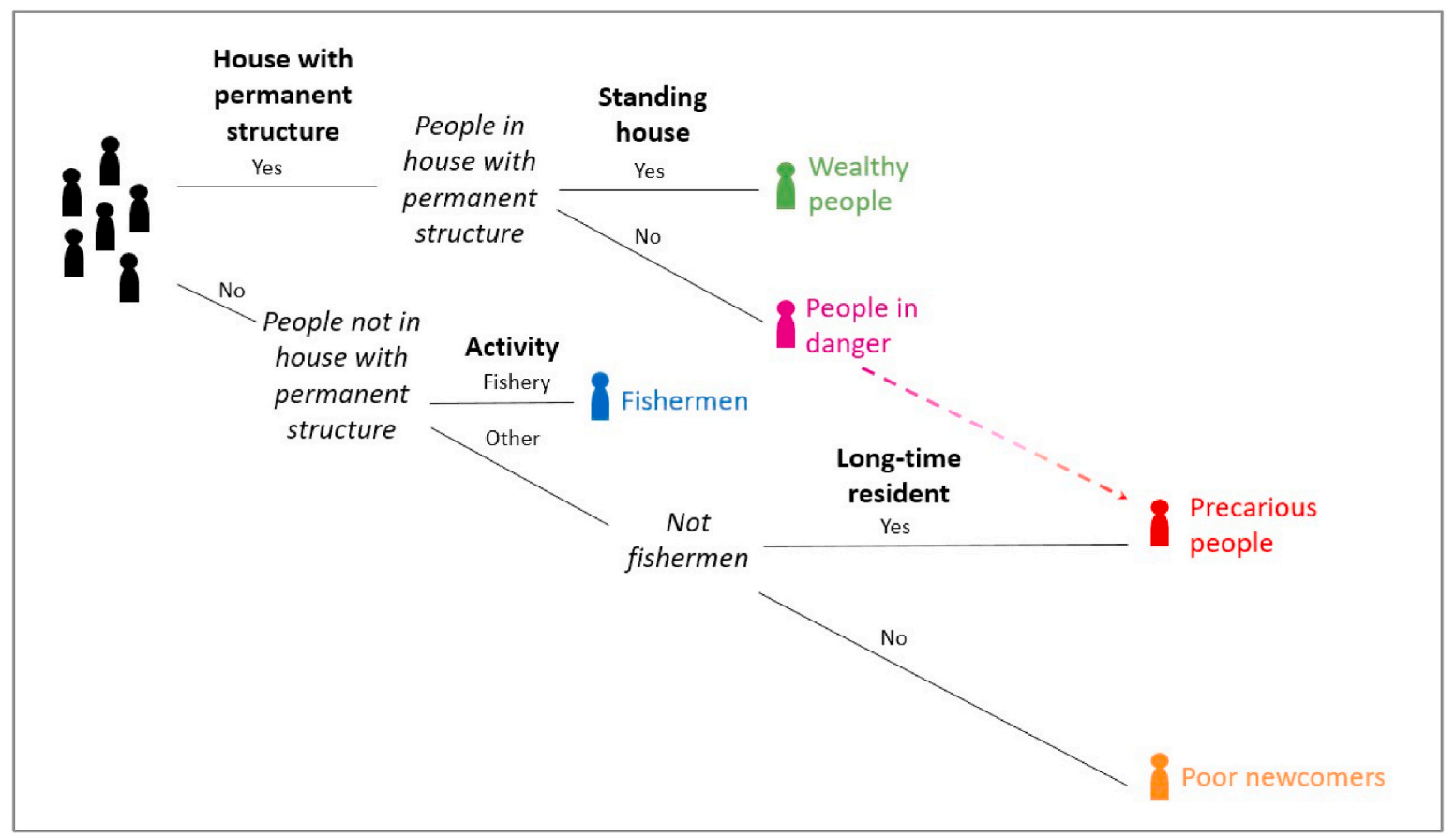

Fig. 5. Typology of the population in the study area (source: data recorded during the fieldwork in 2014).
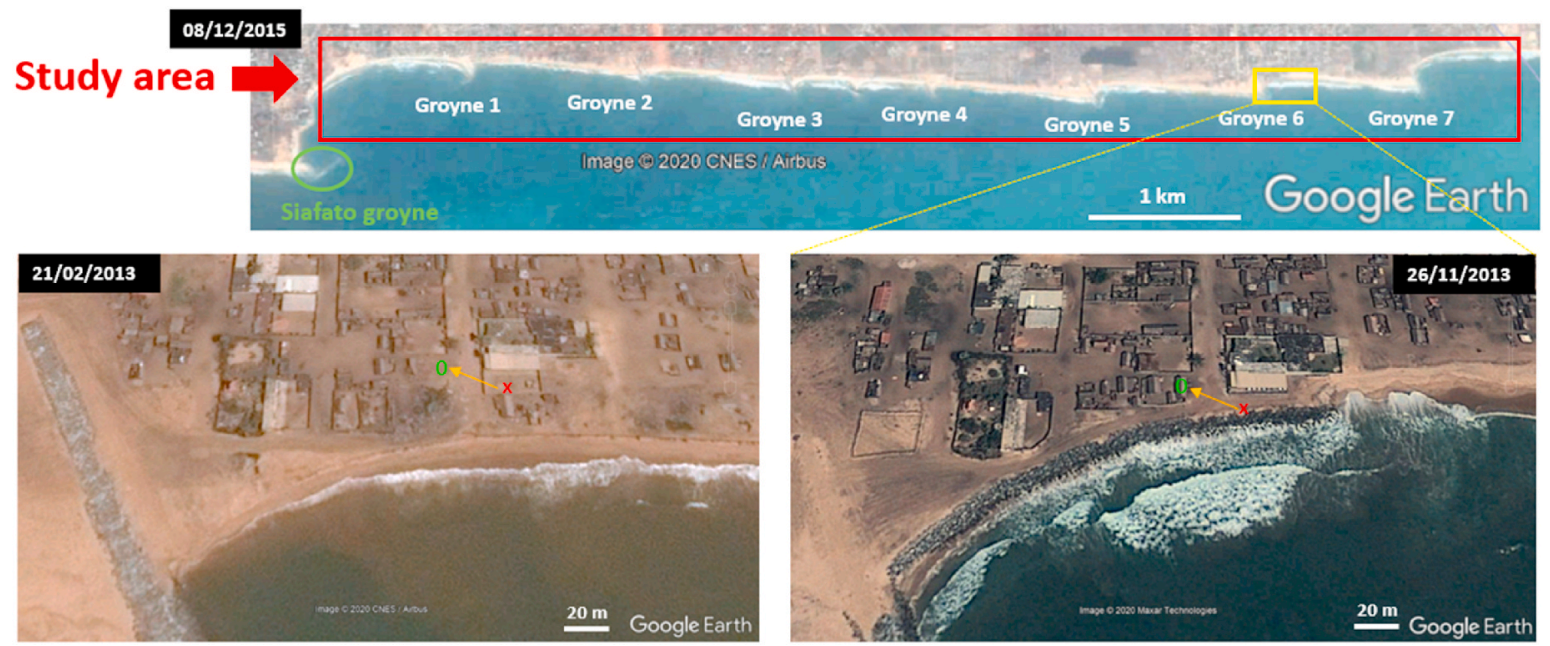

Fig. 6. Example of a very short movement of one household (red cross: house of origin, green circle: house of destination).

live again in houses with a permanent structure located in the study area, currently very close to the stretch of the sea. Two cases were observed: older houses protected with sandbags and big stones and more recent houses, deliberately unfinished because of the risk to be destroyed. If these houses are destroyed by the sea, their inhabitants will not have the financial and social capitals to move to safe areas and would become precarious people in the risk zone.

- Fishermen (blue in Fig. 7) [7 direct, hundreds by 4 indirect, hundreds by local authorities]: they are native of the region of Grand-Popo (on the coast $90 \mathrm{~km}$ west of Cotonou) or from parents born in the region of Grand-Popo. They arrived in this coastal area in the early 1970s to enjoy better living conditions and more employment opportunities. Since their arrival, they have made successive movements along the coastline because of the progressive sea's encroachment. Their first establishments are now up to $500 \mathrm{~m}$ into the sea. A fisherman told us: « Je fais des déplacements successifs depuis le temps de mes parents. Il faut toujours reculer un peu mais rester proche de la mer. » [“I made several successive movements since the time of my parents. You always have to step back a bit at the same time staying close to the sea."] Sometimes, they were evicted by a landowner or by the authorities, notably in the framework of work for coast protection between 2009 and 2013. The resulting loss of assets and capital necessary for building a new house caused their vulnerability to increase with each movement. Fishermen have been now and then sensitised by the authorities to leave the risk zone but they wanted to stay there to remain close to their economic activities. Another fisherman said: «Je suis un pêcheur, issue d'une famille de pêcheurs, je ne peux rien faire d'autre, je dois rester près de la mer, c'est seulement la mort qui peut me séparer de la mer. » [“As a fisherman from a fishing family, I cannot do anything else, I have to stay close to the sea, it is only death that can separate me from the sea."]

- Precarious people (red in Fig. 7) [7 direct, hundred by 3 indirect, thousands by local authorities]: these people became poor in the risk zone after the destruction of their house by the sea's encroachment 


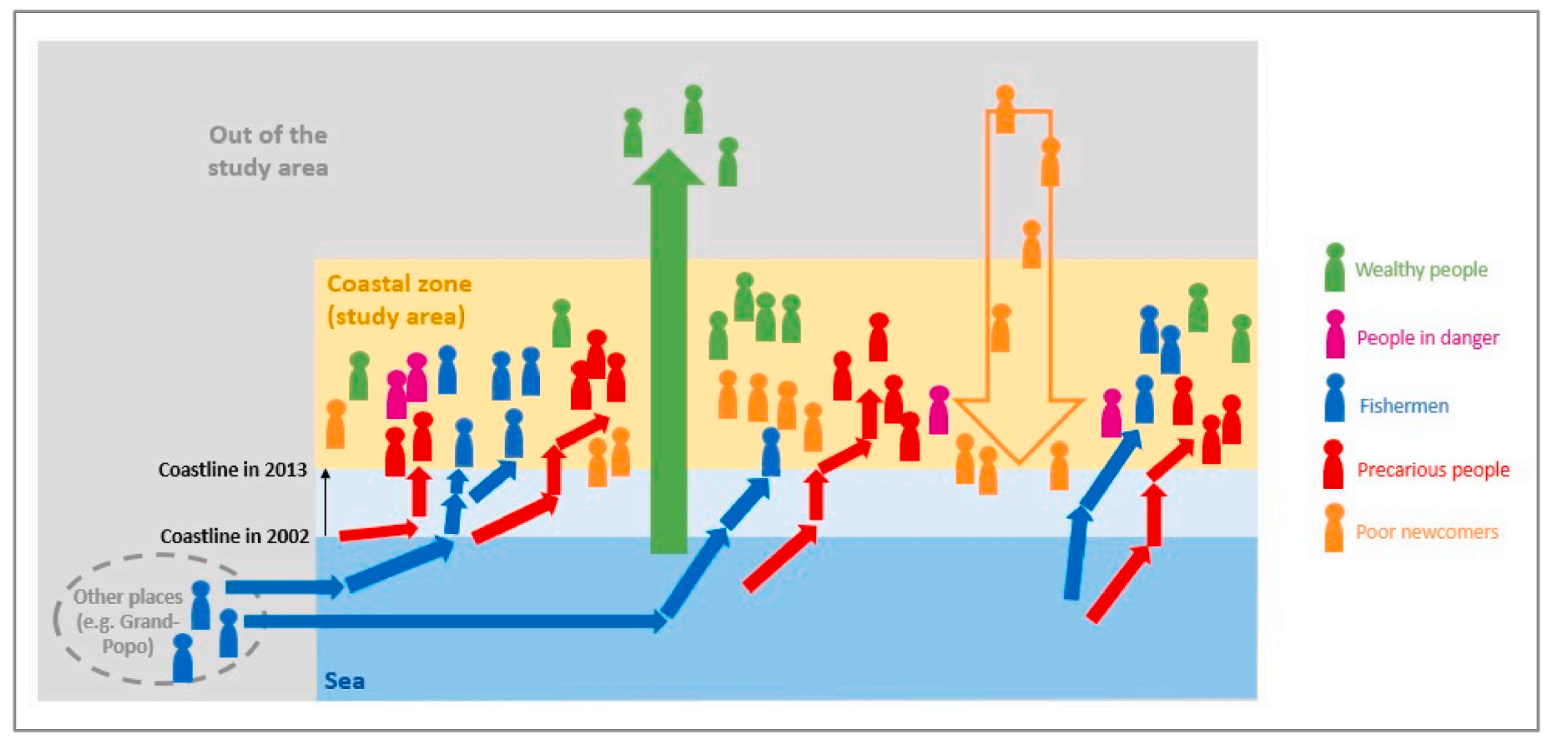

Fig. 7. Representation of the main movements of different profiles of people (source: data recorded during the survey in 2014 and in 2018 ).

and without resources to leave the risk zone. They were born in the coastal area or came from other districts of Cotonou, as from the zone converted into the large market of Danktopa in the 1960s. Originally, they often owned a house with permanent structure (brick walls), located 'in the current sea', i.e. several hundred meters from the current coastline. At that time, their houses were (very) far from the sea. Because of the progressive sea's encroachment, they lost their house and their land and have made successive movements, sometimes of a few meters, in the risk zone (Fig. 6). Some had made a dozen of short movements in the last 10 years. They squatted in the deserted damaged houses, built their makeshift house behind the ruins of destroyed villas or protected them with the bricks moved from old walls. An owner of a house engulfed in the sea told us: " Notre maison a été détruite il y a 8 ans, nous sommes ici depuis 1 an sur le terrain d'une connaissance partie vers Porto Novo. Quand nous sommes arrivés la mer était plus loin mais aujourd'hui nous avons vraiment peur, nous sommes en train d'amener nos briques plus loin dans une autre parcelle plus éloignée de la mer. » ["Our house was destroyed 8 years ago; we have been here for 1 year on a parcel of an acquaintance who has gone to Porto Novo. When we arrived, the sea was further away but today we are really afraid, we are carrying our bricks to another parcel further away from the sea."]. These coping strategies are very temporary allowing at best to gain a few months while their makeshift houses may be engulfed by the sea within a few hours during a storm event. A woman said: "Nous écoutons et observons la mer. C'est le bruit qui donne l'alerte et le fait qu'avec le haut des vagues on ne voit plus l'horizon. Dans ces cas-là, une personne dort à même le sol et réveille les autres rapidement si l'eau rentre dans la maison car en quelques minutes, l'eau peut tout emporter. » ["We listen and observe the sea. It is the noise that gives the warning and the fact that with the top of the waves we no longer see the horizon. In these cases, one of us sleeps on the floor and wakes up the others quickly if the water enters the house because, in a few minutes, the water can take everything away."]. These precarious people wanted to leave the risk zone but due to the lack of necessary resources to re-establish livelihoods elsewhere, they become exposed to increasingly severe environmental shocks and stresses in situ.

- Poor newcomers (orange in Fig. 7) [3 direct, a dozen by 1 indirect]: people who arrived recently in the risk zone from rural areas or other countries of the sub-region. Interviews have taught us that some households even came from abroad (e.g. Togo, Nigeria). They were already poor before their settlement in this zone and had no money to pay rent elsewhere in the city. A woman from Togo told us: « Je suis venue pour travailler, je fais des ménages. Je n'ai pas trouvé de chambre moins chère en dehors de cette zone. Et il y avait de l'espace libre ... Je suis arrivée après les autres et quelques personnes sont encore arrivées après moi. " ["I came to work, I did housework. I could not find a cheaper room outside that area. And there was free space ... I came after the others but a few people still came after me."] In rapidly expanding cities and in the absence of space for settlement accessible to the urban poor, more-at-risk zones are likely to house a larger proportion of the lower-income population [51,52]. In Cotonou, these people live in informal settlements that they built on land where the owner is unknown. They move slightly when the sea threatens them or when their precarious house is destroyed by the waves.

\subsection{Risk perception and responses of inhabitants}

Based on data recorded during the surveys carried out with residents in 2014 and in 2018, we mapped the rate of affected people, their emotions towards coastal erosion and its impacts, their perception of the effectiveness of the groynes and their responses to risk on a timeline presenting the periods of the construction of coastal protection structures (in 2013) as the reference (Fig. 8).

Before the coastal protection by the groynes in 2013 , the vast majority of people settled in the study area was affected by erosion and almost all used movements as a response to risk (Fig. 8). This is in line with the (micro) movements widely mentioned as common measures by fishermen, precarious people and poor newcomers in the testimonies collected in July 2014. Without other alternatives, they often adopted several very temporary coping strategies. Also, according to the 2018 survey, anxiety was a feeling shared by many people before 2013 and it appeared that installation of groynes brought serenity to most of the inhabitants (Fig. 8). In July 2014, all respondents reported being affected by erosion. Almost three-quarter of respondents feared the sea and one on five was more afraid of eviction, by the landowner or authorities. One respondent evoked the fear of the sea and the fear of eviction and only one did not talk about fear (Fig. 8). A few months after the installation of the protection structures, only 3 of the respondents had already observed a positive effect of groynes, 14 said they did not see a positive effect and 3 respondents thought the situation had got worse since the building of the groynes (Fig. 8).

The survey carried out in May 2018 showed that almost all respondents $(n=37)$ recognised the effectiveness of the coastal protection 


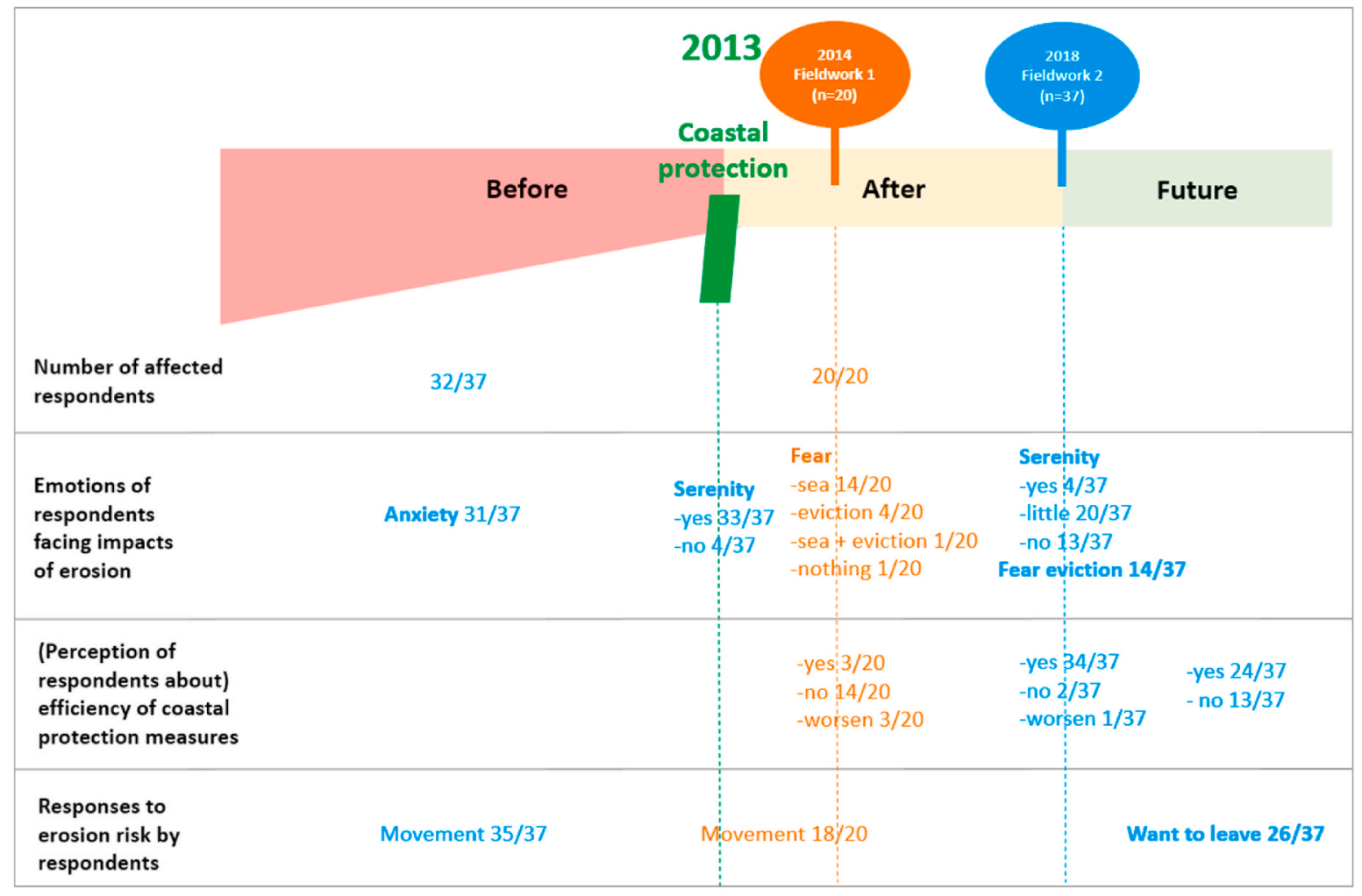

Fig. 8. Risk perceptions and responses of inhabitants (source: data recorded during the survey in 2014 (in brown) and in 2018 (in blue)).

measures 5 years after their construction but only a small number lived in serenity while the others were a little (half of respondents) or not (one third of respondents) serene (Fig. 8). Despite the relatively high level of satisfaction among respondents who had experienced the effectiveness of the groynes to protect the coast, only one third of respondents believed that more groynes would be sufficient to protect them permanently. Moreover, with stabilisation of the coastline, four respondents on ten feared eviction and seven on ten wanted to leave the coastal area but had no alternative (Fig. 8). One of the respondents said: « Nous ne savons où aller, nous dormons à la belle étoile ou sous des abris faits en pagne en priant que la pluie ne s'abatte sur nous. En cette période de saison pluvieuse, cela ne saurait tarder. En plus, nous vivons dans la peur constante qu'ils ne viennent nous déguerpir à nouveau d'ici. Tous nos ustensiles ont été saccagés et nous n'arrivons même plus à nous nourrir comme avant. Les enfants ne peuvent plus aller à l'école car d'où nous avons trouvé refuge, ils ne peuvent se rendre à pied à leur école compte

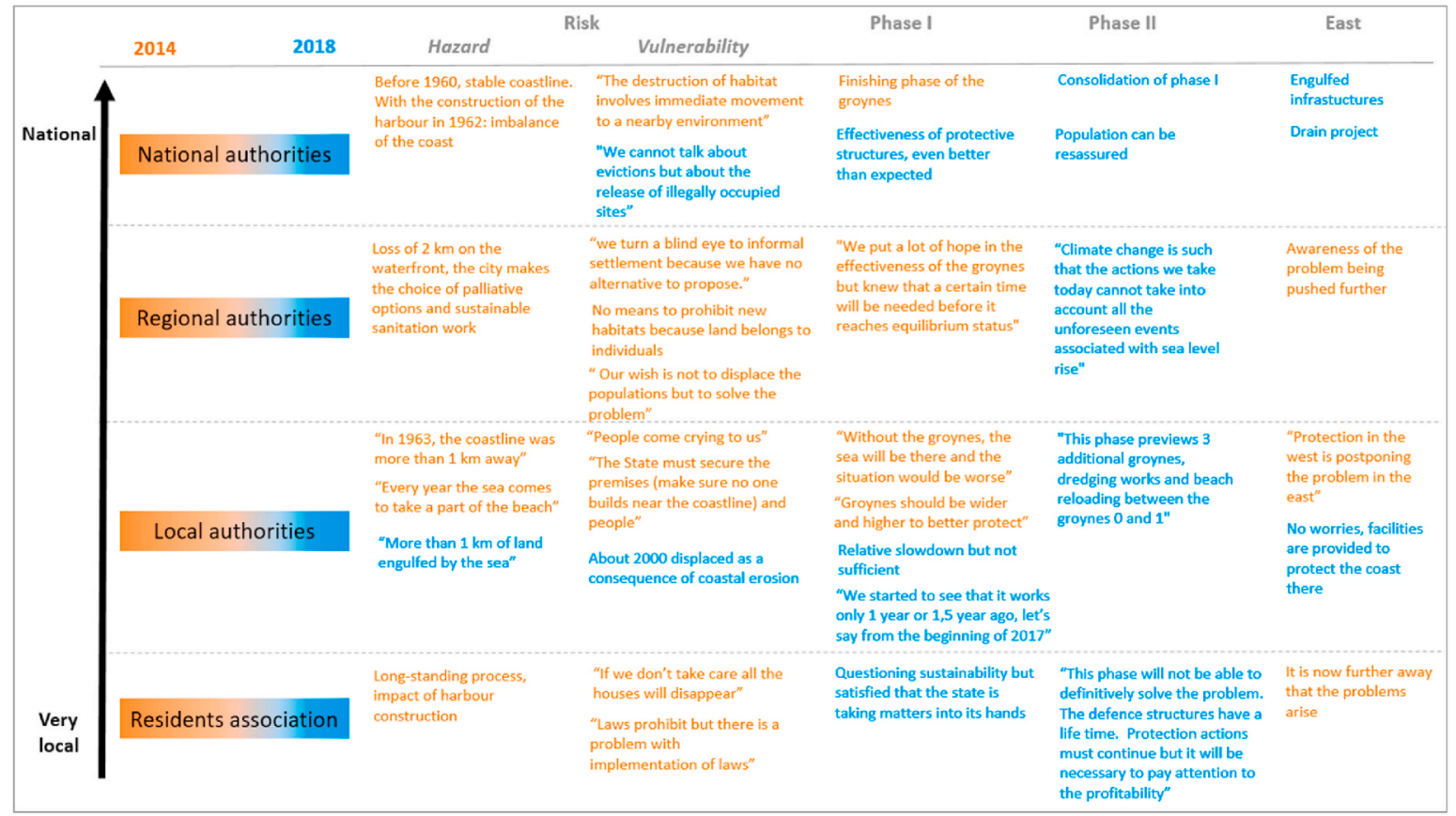

Fig. 9. Risk perception of stakeholders (sources: semi-structured inteviews carried out in 2014 (in brown) and in 2018 (in blue)). 
tenu de la distance et je n'ai pas de quoi leur payer le déplacement ». ["We do not know where to go, we sleep in the open or under shelters made from loincloth praying that the rain will not fall on us. In this period of the rainy season, we don't have to wait for long. Besides, we live in constant fear that they will come and evict us again. All our equipment has been destroyed, and we cannot even feed ourselves as before. Children can no longer go to school because from where we found shelter, they can't walk to their school regarding the distance and I don't have enough money to pay for their transport."]

\subsection{Risk perception of stakeholders}

When we talked about the risk during the semi-structured interviews in 2014, the representative of the national authorities, as well as the member of the residents' association, immediately pointed out the construction of the harbour as being responsible for the coastal erosion in that area (Fig. 9). According to one of the Beninese researchers (a geologist) who we met at the university in 2014, it was known that the construction of the harbour would create problems as it can be read in a publication of Sireyjol [53]. And this has also been repeated by the civil engineer interviewed in 2018 who said: "c'est le port qui a assez dévié les courants pour créer le déficit à l'est ... peut-être que le prolongement de l'épi d'arrêt de sable an un peu aggravé la chose mais le port est assez grand pour avoir causé ce qu'on voit maintenant, donc le mal était déjà fait avec le port " ["it's the harbour that has deviated marine currents enough to create the deficit to the east ... it is possible that the extension of the sand stop groyne made it a little worse but the harbour is big enough to have caused what we see now, so the damage was already done with the harbour]. The respondents from the local and regional authorities rather mentioned the consequences of this coastal erosion, namely $2 \mathrm{~km}$ and $1 \mathrm{~km}$ respectively of land submerged in the sea in this area.

Relating to vulnerability, two main elements emerged from the semistructured interviews carried out in 2014 and 2018. The first relates to the question of legality ("illegally occupied sites", "informal settlement", "prohibit", "laws") and the second to the notion of movement ("immediate movement", "evictions", "to displace populations", "displaced", "dislodge") (Fig. 9). Concerning the first one (the question of legality), a Beninese researcher (environmental sciences) said that there is a major risk for the population settling in the zone. According to him, administratively, no settlement is allowed in this area but, in reality, the situation is more complicated because the land has been acquired by individuals prior to the erosion problem. ${ }^{5}$ As the land belongs to individuals, prohibitions are difficult according to the local authorities. According to another Beninese researcher (law), the problem is the absence of implementing regulations of laws and/or their nonapplication where they are available, non-compliance with legal texts due to the lack of mechanisms to compel communities to meet legal requirements. Moreover, he said that there is a lack of knowledge of these legal texts by local population and a low outreach of their content. Next to that, there is the sensitive issue of informal settlements. Local and regional authorities seemed to be overwhelmed by this situation. Concerning the second one (the notion of movement), every single stakeholder talked about the movements of formal residents and/or informal residents and their comments expressed the complexity of the situation. Dynamics of the at-risk populations have also been mentioned by other stakeholders interviewed in 2014. For one of the actors engaged in climate change adaptation, there is no other solution than to dislodge people (referring to informal residents) and for the agent of the national agency, mandatory displacements are needed in case of coastal erosion,

\footnotetext{
${ }^{5}$ It was only in 1995 that all residents in unsuitable coastal areas got restitution by receiving new parcels. Apart from this case, only households who had been displaced as a result of protective work had been compensated against leaving.
}

especially for those who could be hosted by relatives (relating to formal residents).

Results also indicated that stakeholders involved in erosion risk management have similar perceptions of the effectiveness of coastal protection structures (Fig. 9). In 2014, just after the finishing of the phase I, regional authorities put a lot of hope in the groynes to solve the problem and local authorities highlighted that the situation would be worse without groynes. However, perceptions collected in 2018 differ somewhat between stakeholders in terms of their long-term effectiveness. While a very high satisfaction was expressed from national authorities ("groynes more effective than expected"), not sufficient action for coastal management by national authorities was mentioned by the local authorities and questionable sustainability of the solution was mentioned by the residents' association. The implementation of the phase II has shown that the phase I indeed was not sufficient but also proved that there was a follow-up to fight this phenomenon even though a researcher said that the government's action came late.

Finally, all stakeholders mentioned that the problem has been transferred to the East of Cotonou, but they did not seem concerned about the situation that, according to respondents, should be tackled by the national and local authorities (Fig. 9).

\section{Discussion of results}

The coastal erosion recorded in Cotonou, leading to coastline retreat and subsequent land loss, would not be an issue of concern if it had not affected local populations, infrastructures and economic development. In this part, we successively discuss the (im-)mobility of people in the risk zone and the comparison between people who experience the risk and those who manage the risk.

\section{1. (Im-)mobility of people in the risk zone}

Our results are consistent with the findings of a recent study conducted in a coastal area of Ghana showing a non-linear relationship between environmental risk and migration and demonstrating the complexity of the migration process and decision-making [54]. We showed that only the wealthy people, a minority of directly affected people in our study area, definitely leave the coastal area of Cotonou if they are sure no protection can be efficient. These are, strictly speaking, the only people who migrate out of the risk zone, and this is made possible because they have the necessary social and/or financial capital. For the precarious population, the lack of sufficient resources hinders their migration as an adaptation strategy and limits the potentially available migration destinations [55]. These people are involuntary non-migrants as defined by Carling [56]; they are "trapped" in the risk zone $[57,58]$. Before the stabilisation of the coastline by groynes, these people, unable to leave, simply made short perpendicular or parallel movements close to the coastline and feared to be engulfed by the sea. This confirms previous case studies which proved that it is not generally the poorest people who migrate [40] and that environmental factors intermingle with social and economic drivers to trigger the migration decision $[59,60]$. The case of fishermen is particular and adds a new dimension to the concept of the immobile population. Indeed, in 2014, they were not satisfied with the new infrastructure to protect the coast and feared being engulfed by the sea while in 2018 , they wanted to stay close to the coastline for their activities, but they feared that they will be evicted. In the risk zone, they are voluntary non-migrants as identified by Carling [56] and need to be protected as well as precarious people. Based on these results, we claim that the widespread statement that if coastal at-risk settlers do not adapt in any way, land and property can be lost and migration will be a direct consequence of coastal erosion [43] needs to be qualified. Moreover, it is too simplistic to count people who are settled in a low-level area to predict future migration caused by sea level rise. Finally, our results highlight that the coastal area of Cotonou receives more migrants (poor newcomers) than it loses (wealthy 
people). This is consistent with available literature suggesting that globally, there is a net-migration into hazardous areas [61-63].

In this kind of area characterised by highly dynamic settlements [64], our study illustrates that coastal erosion leads thus to a rearrangement of relative social vulnerability in the risk zone, as in Densu Delta in Ghana [27]. Image analyses showed that one enclosed parcel originally destined for one villa hosts a dozen makeshift houses a few years later (see Fig. 10, below, in white, green and blue circles). Today, most of these precarious houses do no longer exist because they were destroyed during evictions in 2018 in order to regain the good reputation of this stabilised area that will now be developed for the purpose of tourism [65]. As the detection of area-wide fast-moving processes remains very difficult in developing countries due to the lack of official statistics [66] and data about small disasters [38], we showed that the comparison of satellite images can be a useful tool. It was impossible to find the same people for the survey in 2014 and 2018, which further highlights the rapidity of settlement changes in the study area.

\subsection{Comparison between people who experience the risk and those who manage the risk}

It is known that the risk perception of non-experts (i.e. inhabitants of the risk zone) is different from the perception and knowledge of the "experts" and managers [67,68]. A study led in Brittany (France) showed that the inhabitants most directly concerned by coastal risks tend to underestimate the impact of coastal risks [69]. The situation seemed to be different in the context of Cotonou where the vast majority of inhabitants knows the problems related to the risk of erosion, having been and/or being directly affected by the effects of coastal erosion. A previous study led in Benin showed differences in risk perception depending on many factors, for example their ethnicity, education and age [70]. Facing the coastal erosion risk, most of the inhabitants met during our fieldworks adopted very temporary coping strategies because of lack of other choices. We also saw that their feelings change quickly depending on events, and that the reduction of hazard through the implementation of coastal protection structures, whose effectiveness is widely recognised, is not sufficient to render them serene. Today, beyond the uncertainty about the long-term effectiveness of these groynes, it is above all the fear linked to evictions that dominates for inhabitants, in particular for fishermen, the precarious population and poor newcomers.

The vision of the component "hazard" of the risk is common for all levels of stakeholders: coastal erosion, mainly explained by the construction of the harbour, leads to a significant loss of land to the sea. There are sometimes differences of opinion on the extent of the erosion problem and impacts, but all agree on the problem. During an interview, a respondent from the local authorities strongly affected by coastal erosion and house loss said «... plus de $1 \mathrm{~km}$ a été englouti par la mer et près de 2000 personnes ont été déplacées de ce fait ... » ["... more than 1 $\mathrm{km}$ of land has been engulfed by the sea and nearly 2000 people have been displaced due to this ..."]. Another respondent of local authorities mentioned about $2 \mathrm{~km}$ of land lost to the sea while the loss evaluated from satellite image analyses was about $570 \mathrm{~m}$ in 2005 [17] and $700 \mathrm{~m}$ in 2018 [65]. This shows that the local authorities do not have reliable figures on the risk to which its inhabitants are exposed and confirms the importance of providing decision-makers with scientific information for improved action planning.

The vision of the component "vulnerability" to the risk by stakeholders is not as clear. Cases of individuals/households settling in formal settlements must be distinguished from those in informal settlements. While the "cleaning" of illegally occupied sites is evident for stakeholders at the national level, our study has shown that at a local level, stakeholders see things differently but seemed to be overwhelmed by the situation. With the implementation of the phases I and II, the respondent from the national authorities said that the population can be reassured, but it appears that this was addressed only formally to the population. It seems that since the stabilisation of the coastline in the study area, the risk of coastal erosion is under control as far as risk managers are concerned. A new development of the area is ongoing with new hotel infrastructures and sportive facilities [65]. Stakeholders were less interested in the risk reported further east and claimed that there exist projects to stop erosion.

A hazard and vulnerability assessment of coastal erosion and sea flooding is an essential first step for planning and decision-making. In order to address the negative impacts of coastal erosion processes, policymakers, coastal managers and opinion leaders need evidence-based
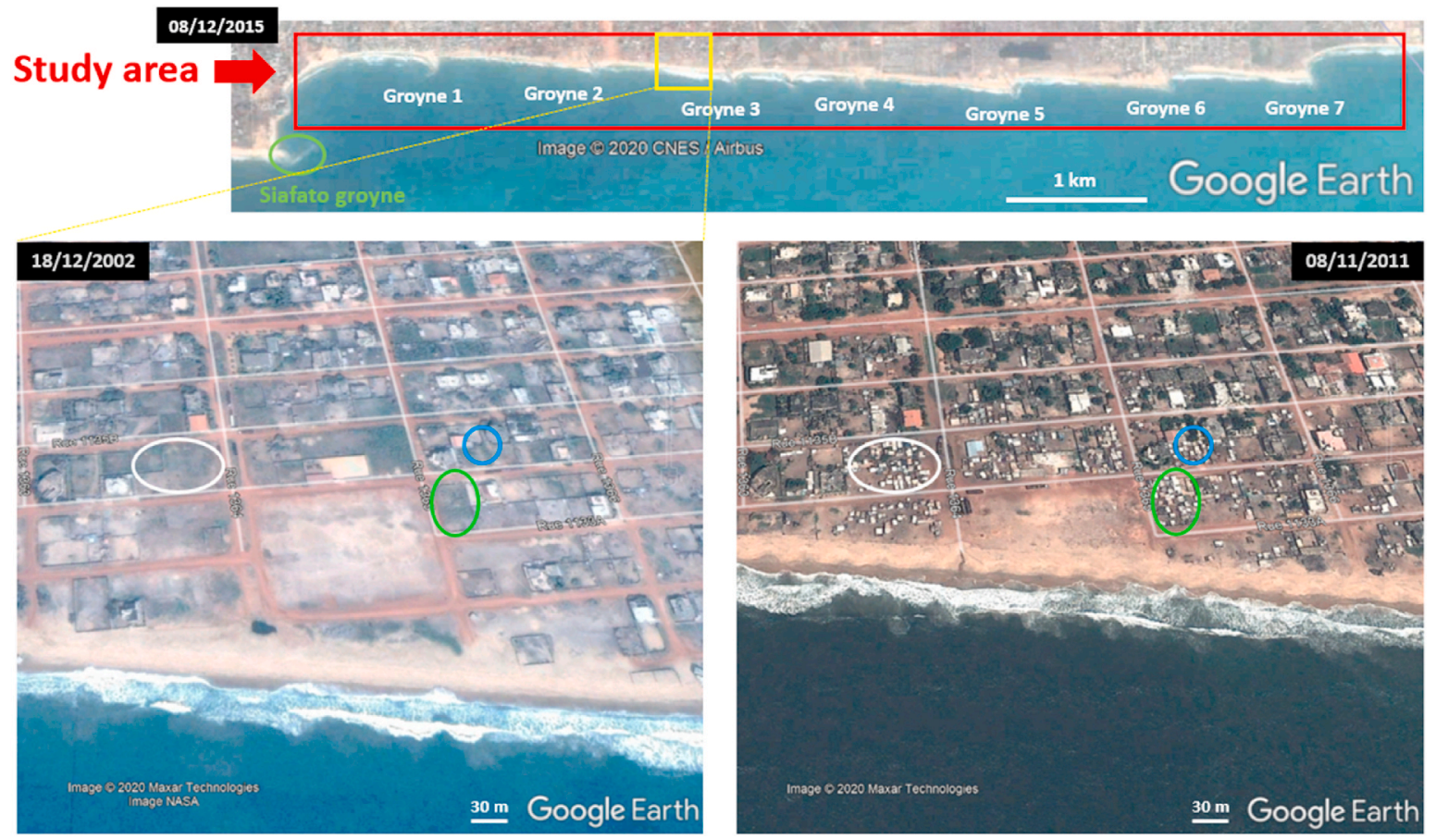

Fig. 10. Evolution of the human settlement in a part of the study area between 2002 and 2011. 
information on the current status and forecasts of coastal vulnerability. Determining hot-spots of coastal vulnerability allows for proper implementation of long-term policy, such as restriction of development in vulnerable areas, as well as the allocation of resources in the short-term [3]. For vulnerability, it is therefore important to make a distinction between different types of residents' profiles. The typology we have proposed may be useful in this respect.

From above, we can conclude that the national authorities manage more or less, for the moment the component "hazard" but the component "vulnerability" is not solved. For inhabitants of the study area, in a context of increasing vulnerability with time, stress linked to (semi) natural hazard has progressively been replaced by stress induced by late and incomplete human management of these processes.

\section{Final remarks}

Coastal erosion and sea flooding, as urban floods in Africa, occur as the results of multiple interacting social and environmental processes that are poorly monitored [27]. The coastal area of Cotonou, highly urbanised, clearly is a risk-prone zone as affected by a fast erosion for several decades. The speed of coastal erosion over the last two decades was impressive and temporary stabilisation concerned only a few kilometres of coastline. Our results also show that the vulnerability of the population in the study area has always been strongly influenced by the governance of the territory. There is an urgent need to protect the population and to make the coastal area more resilient. A first step was done with the construction of the groynes, but this is not sufficient. Even though these structures have been efficient in containing erosion updrift, they engender, nevertheless severe erosion downdrift by blocking sand to drift along the shore [20]. Enforcement of planning regulations, cooperation between multiple levels of governance and with other countries, the involvement of local communities [70,71] and the application of the Kampala Convention ${ }^{6}$ are factors that applied all together, will allow reaching this objective.

\section{Declaration of competing interest}

The authors declare that they have no known competing financial interests or personal relationships that could have appeared to influence the work reported in this paper.

\section{Acknowledgements}

The research leading to these results has received funding from the European Union Seventh Framework Programme FP7/2007-2013 under grant agreement no. 603864 and from the Commission de la Coopération au Développement de l'Académie de Recherche de d'Enseignement Supérieur (ARES-CCD).

\section{Appendix A. Supplementary data}

Supplementary data to this article can be found online at https://doi. org/10.1016/j.ijdrr.2020.101882.

\footnotetext{
${ }^{6}$ The Kampala convention is the first legally binding instrument that addresses the specific needs of internally displaced persons in their own country [73]. Benin, like other nations that have ratified the convention, must now incorporate it into national legislation and develop policies on internally displaced persons which emanate from the central government to apply to all lower political levels so that the agreement can work in practice. If integrated and applied, it could help Benin to deal with the displacement of people, both current and future, caused not only by conflicts, but also by natural disasters and other effects of climate change, by development, and even by the major trends such as population growth and rapid urbanisation.
}

\section{References}

[1] O. Coca-Domínguez, C. Ricaurte-Villota, Validation of the hazard and vulnerability analysis of coastal erosion in the caribbean and pacific coast of Colombia, J. Mar. Sci. Eng. 7 (8) (2019) 260, https://doi.org/10.3390/jmse7080260.

[2] A.K. Armah, G. Wiafe, D.G. Kpelle, Sea level rise and coastal biodiversity in West Africa: a case study from Ghana, in: P.S. Low (Ed.), Climate Change and Africa, Cambridge University Press, Cambridge, 2005, pp. 204-217, https://doi.org/ 10.1017/CBO9780511535864.029.

[3] I. Boateng, G. Wiafe, P.N. Jayson-Quashigah, Mapping vulnerability and risk of Ghana's coastline to sea level rise, Mar. Geodes. 40 (1) (2017) 23-39, https://doi. org/10.1080/01490419.2016.1261745.

[4] K.M. Dossou, B. Glehouenou-Dossou, The vulnerability to climate change of Cotonou (Benin) the rise in sea level, Environ. Urbanization 19 (2007) 65-79, https://doi.org/10.1177/0956247807077149.

[5] S.P. Leatherman, Social and economic costs of sea level rise, Int. Geophys. 75 (2001) 181-223, https://doi.org/10.1016/S0074-6142(01)80011-5.

[6] O.H. Pilkey, J.A.G. Cooper, Society and sea level rise, Science 303 (2004) 1781-1782, https://doi.org/10.1126/science.1093515.

[7] K. Appeaning Addo, Shoreline morphological changes and the human factor. Case study of Accra Ghana, J. Coast Conserv. 17 (2013) 85-91, https://doi.org/ 10.1007/s.11852-012-0220-5.

[8] A. Giardino, R. Schrijvershof, C.M. Nederhoff, H. de Vroeg, C. Brière, P.K. Tonnon, et al., A quantitative assessment of human interventions and climate change on the West African sediment budget, Ocean Coast Manag. 156 (2018) 249-265, https:// doi.org/10.1016/j.ocecoaman.2017.11.008.

[9] M.A.A. Hoque, N. Ahmed, B. Pradhan, S. Roy, Assessment of coastal vulnerability to multi-hazardous events using geospatial techniques along the eastern coast of Bangladesh, Ocean Coast Manag. 181 (2019) 104898, https://doi.org/10.1016/j. ocecoaman.2019, 104898.

[10] IPCC (Intergovernmental Panel on Climate Change), in: R.K. Pachauri, L.A. Meyer (Eds.), Climate Change 2014: Synthesis Report. Contribution of Working Groups I, II and III to the Fifth Assessment Report of the Intergovernmental Panel on Climate Change [Core Writing Team, (eds.), IPCC, Geneva, Switzerland, 2014, p. 151.

[11] S. Jevrejeva, J.C. Moore, A. Grinsted, Sea level projections to AD2500 with a new generation of climate change scenarios, Global Planet. Change 80 (2012) 14-20, https://doi.org/10.1016/j.gloplacha.2011.09.006.

[12] K.Q. Zhang, B.C. Douglas, S.P. Leatherman, Global warming and coastal erosion, Climatic Change 64 (2004) 41-58, https://doi.org/10.1023/B: CLIM.0000024690.32682.48.

[13] J.P. Ericson, C.J. Vörösmarty, S.L. Dingman, L.G. Ward, M. Meybeck, Effective sea level rise and deltas: causes of change and human dimension implications, Global Planet. Change 50 (1) (2006) 63-82, https://doi.org/10.1016/j. gloplacha.2005.07.004.

[14] A. Melet, R. Almar, B. Meyssignac, What dominates sea level at the coast: a case study for the Gulf of Guinea, Ocean Dynam. 66 (2016) 623-633, https://doi.org/ 10.1007/s10236-016-0942-2.

[15] B. Touré, K.F. Kouamé, W. Souleye, C. Collet, K. Affian, A. Ozer, J.-P. Rudant, J. Biémi, L'influence des actions anthropiques dans l'évolution historique d'un littoral sableux à forte dérive sédimentaire: la baie de Port-Bouët (Abidjan, Côte d'Ivoire), Géomorphol. Relief, Process. Environ. 18 (3) (2012) 369-382, https:// doi.org/10.4000/geomorphologie.9990.

[16] C. Codjia, Application de la télédétection à l'étude des changements urbains et des transformations du littoral à Cotonou (Bénin). Universités francophones, Actualité scientifique, 1997, pp. 299-306.

[17] C. Kaki, R.A. Laïbi, L.M. Oyédé, Evolution of Beninese coastline from 1963 to 2005: causes and consequences, Br. J. Environ. Clim. Change 1 (2011) 216-231.

[18] E.E. Ago, F. Petit, P. Ozer, Analyse des inondations en aval du barrage de Nangbeto sur le fleuve Mono (Togo et au Bénin), Geo-Eco-Trop 29 (2005) 1-14.

[19] P. Ozer, Y.-C. Hountondji, F. de Longueville, Evolution récente du trait de côte dans le Golfe du Bénin. Exemples du Togo et du Bénin, Geo-Eco-Trop 41 (2017) 529-541.

[20] A. Ndour, R.A. Laïbi, M. Sadio, C.G. Degbe, A.T. Diaw, L.M. Oyédé, et al., Management strategies for coastal erosion problems in West Africa: analysis, issues, and constraints drawn from the examples of Senegal and Benin, Ocean Coast Manag. 156 (2018) 92-106, https://doi.org/10.1016/j.ocecoaman.2017.09.001.

[21] É.H. Prudencio, B. Singh, P. André, Vulnérabilité de la zone côtière du Bénin à un rehaussement relatif du niveau marin: état de la question et préconisations/ Vulnerability of the Coastal Zone of Benin to a Relative Sea level Rise: state of the Problem and Recommendations, Annales de géographie, JSTOR 623 (2002) 25-40.

[22] K. Amoani, K. Appeaning Addo, W. Laryea, Short-term shoreline evolution trend assessment: a case study in Glefe, Ghana, Jamba: J Disaster Risk Stud 4 (2012) 1-7, https://doi.org/10.4102/jamba.v4i1.45.

[23] G. Amoako, F.E. Boamah, The three-dimensional causes of flooding in Accra, Ghana, Int. J. Urban Sustain. Dev. 7 (1) (2014) 109-129, https://doi.org/10.1080/ 19463138.2014.984720.

[24] F.E. Jonah, O. Adams, D.W. Aheto, R.E. Jonah, E.A. Mensah, Coastal zone management challenge in Ghana: issues associated with coastal sediment mining, J. Coast Conserv. 21 (2017) 343-353, https://doi.org/10.10007/s11852-0170511-y.

[25] T.S. de Andrade, P.H.G. de Oliveira Sousa, E. Siegle, Vulnerability to beach erosion based on a coastal processes approach, Appl. Geogr. 102 (2019) 12-19, https:// doi.org/10.1016/j.apgeog.2018.11.003.

[26] M.L.A. Gomez, O.J. Adelegan, J. Ntajal, D. Trawally, Vulnerability to coastal erosion in the Gambia: empirical experience from Gunjur, International Journal of 
Disaster Risk Reduction 45 (2020) 101439, https://doi.org/10.1016/j. ijdrr.2019.101439.

[27] F. Frick-Trzebitzky, R. Baghel, A. Bruns, Institutional bricolage and the production of vulnerability to floods in an urbanising delta in Accra, International Journal of Disaster Risk Reduction 26 (2017) 57-68, https://doi.org/10.1016/j. ijdrr.2017.09.030.

[28] F.E. Jonah, E.A. Mensah, R.E. Edziyie, N.W. Agbo, D. Adjei-ris, Coastal erosion in Ghana: causes, policies, and management, Coast. Manag. 44 (2) (2016) 116-130, https://doi.org/10.1080/08920753.2016.1135273.

[29] K.C. Seto, Exploring the dynamics of migration to mega-delta cities in Asia and Africa: contemporary drivers and future scenarios, Global Environ. Change 21 (2011) S94-S107, https://doi.org/10.1016/j.gloenvcha.2011.08.005.

[30] M.A. Islam, D. Mitra, A. Dewan, S.H. Akhter, Coastal multi-hazard vulnerability assessment along the Ganges deltaic coast of Bangladesh-A geospatial approach, Ocean Coast Manag. 127 (2016) 1-15, https://doi.org/10.1016/j. ocecoaman.2016.03.012.

[31] B. Sahoo, P.K. Bhaskaran, Multi-hazard risk assessment of coastal vulnerability from tropical cyclones-A GIS based approach for the Odisha coast, J. Environ. Manag. 206 (2018) 1166-1178, https://doi.org/10.1016/j.jenvman.2017.10.075.

[32] M. Montgomery, The urban transformation of the developing world, Science 319 (2008) 761-764, https://doi.org/10.1126/science.1153012.

[33] D. Balk, G. McGranahan, B. Anderson, Urbanization ad ecosystems: current patterns and future implications, in: G. Martine, G. McGrahanan, M. Montgomery, R. Fernandez-Castilla (Eds.), The New Global Frontier: Urbanization, Poverty and Environment in the $21^{\text {th }}$ Century, UNFPA, 2008, pp. 183-202.

[34] S. Huq, S. Kovats, H. Reid, D. Satterthwaite, Editorial: reducing risks to cities from disasters and climate change, Environ. Urbanization 19 (2007) 3-15, https://doi. org/10.1177/0956247807078058.

[35] P. Narra, C. Coelho, F. Sancho, M. Escudero, R. Silva, Coastal hazard assessments for sandy coasts: appraisal of five methodologies, J. Coast Res. 35 (3) (2019) 574-589, https://doi.org/10.2112/JCOASTRES-D-18-00083.1.

[36] S.B. Adamo, Environmental migration and cities in the context of global environmental change, Current Opinion in Environmental Sustainaibility 2 (2010) 161-165, https://doi.org/10.1016/j.cosust.2010.06.005.

[37] E. Osuteye, C. Johnson, D. Brown, The data gap: an analysis of data availability on disaster losses in sub-saharan African cities, International Journal of Disaster Risk Reduction 26 (2017) 24-33, https://doi.org/10.1016/j.ijdrr.2017.09.026.

[38] D. Balk, M. Montgomery, G. McGranahan, D. Kim, V. Mara, M. Todd, T. Buettner, A. Dorelien, Mapping urban settlements and the risks of climate change in Africa, Asia and South America, in: J.M. Guzmán, G. Martine, G. McGranahan, D. Schensul, C. Tacoli (Eds.), Population Dynamics and Climate Change, UNFPA, IIED, 2009 (Chapter 5, pp. 80-103).

[39] C. Tacoli, Crisis or adaptation? Migration and climate change in a context of high mobility, Environ. Urbanization 21 (2009) 513-525, https://doi.org/10.1177/ 0956247809342182.

[40] D. Wheeler, Quantifying Vulnerability to Climate Change: Implications for Adaptation Assistance, Center for Global Development, 2011. Working Paper 240

[41] S.L. Perch-Nielsen, M.B. Bättig, D. Imboden, Exploring the link between climate change and migration, Climatic Change 91 (2008) 375-393, https://doi.org/ 10.1007/s10584-008-9416-y.

[42] S. Luo, F. Cai, H. Liu, G. Lei, H. Qi, X. Su, Adaptive measures adopted for risk reduction of coastal erosion in the People's Republic of China, Ocean Coast Manag. 103 (2015) 134-145, https://doi.org/10.1016/j.ocecoaman.2014.08.008.

[43] MEHU, Stratégie Nationale de mise en cuvre au Bénin de la Convention Cadre des Nations Unies sur les Changements Climatiques, MEHU, Cotonou, 2003, p. 80.

[44] M. Makponse, B. Hounsou, Dynamique de la côte apres la realisation des épis, ouvrages de protection situés à l'Est de l'épi de Siafato a Cotonou au sud-Bénin, J. Rech. Sci. Université Lomé 19 (1) (2017).

[45] K.H. Choi, J.S. Kim, J.C. Lee, Migration of coastal erosional hotspots due to coastal protection structures, Special Issue, No. 75, in: A. Vila-Concejo, E. Bruce, D. M. Kennedy, R.J. McCarroll (Eds.), Proceedings of the 14th International Coastal Symposium (Sydney, Australia). Journal of Coastal Research, 2016, pp. 1062-1066. Coconut Creek (Florida), ISSN 0749-0208.

[46] C.G.E. Degbe, Evolution du trait de côte du littoral béninois de 2011 à 2014, Sciences de la vie, de la terre et agronomie 5 (1) (2017).

[47] C. Meur-Ferec, E. Guillou, Interest of Social Representations Theory to grasp coastal vulnerability and to enhance coastal risk management, PsyEcology 11 (1) (2019) 78-89, https://doi.org/10.1080/21711976.2019.1644003f.

[48] W. Donner, H. Rodriguez, Population composition, migration and inequality: the influence of demographic changes on disaster risk and vulnerability, Soc. Forces 87 (2008) 1089-1114, https://doi.org/10.1353/sof.0.0141.

[49] D. Potts, The slowing of sub-Saharan Africa's urbanization: evidence and implications for urban livelihoods, Environ. Urbanization 21 (2009) 253-259, https://doi.org/10.1177/0956247809103026.

[50] P. Sireyjol, Transit littoral et conception des ports: l'exemple du port de Cotonou (Dahomey), La Houille Blanche 5-6 (1977) 401-408.
[51] S.N.A. Codjoe, F.H. Nyamedor, J. Sward, D.B. Dovie, Environmental hazard and migration intentions in a coastal area in Ghana: a case of sea flooding, Popul. Environ. 39 (2017) 128-146, https://doi.org/10.1007/s11111-017-0284-0.

[52] R. McLeman, B. Smit, Migration as an adaptation to climate change, Climatic Change 76 (2006) 31-53, https://doi.org/10.1007/s10584-005-9000-7.

[53] J. Carling, Migration in the age of involuntary mobility: theorical reflections and Cape Verdean experiences, Journal of Ethic and Migration Studies 28 (2002) 5-42, https://doi.org/10.1080/13691830120103912.

[54] R. Black, N.W. Arnell, W.N. Adger, D. Thomas, A. Geddes, Migration, immobility and displacement outcomes following extreme events, Environ. Sci. Pol. 27 (2013) S32-S43, https://doi.org/10.1016/j.envsci.2012.09.001.

[55] K. Warner, T. Afifi, Enhancing adaptation options and managing human mobility: the united nations framework convention on climate change, Soc. Res.: Int. Q. 81 (2) (2014) 299-326.

[56] R. Bilsborrow, Collecting data on the migration-environment nexus, in: F. Lackzo, C. Aghazarm (Eds.), Migration, Environment and Climate Change: Assessing the Evidence, IOM, UNU-EHS, CCEMA, Rockefeller Foundation, 2009, pp. 115-198.

[57] R. Black, W.N. Adger, N.W. Arnell, S. Dercon, A. Geddes, D. Thomas, The effect of environmental change on human migration, Global Environ. Change 21 (2011) S3-S11, https://doi.org/10.1016/j.gloenvcha.2011.10.001.

[58] A. de Sherbinin, A. Schiller, A. Pulsipher, The vulnerability of global cities to climate hazards, Environ. Urbanization 19 (2007) 39-64, https://doi.org/ 10.1177/0956247807076725.

[59] J. Hardoy, G. Pandiella, Urban Poverty and vulnerability to climate change in Latin America, Environ. Urbanization 21 (2009) 203-224, https://doi.org/10.1177/ 0956247809103019.

[60] A. de Sherbinin, M. Levy, S. Adamo, K. MacManus, G. Yetman, V. Mara, L. Razafindrazay, B. Goodrich, T. Srebotnjak, C. Aichele, P. Pistolesi, Migration and risk: net migration in marginal ecosystems and hazardous areas, Environ. Res. Lett. 7 (2012), 045602, https://doi.org/10.1088/1748-9326/7/4/045602.

[61] U. Sturm-Hentschel, A.C. Braun, S. Hinz, J. Vogt, Detecting and characterizing settlement changes in developing countries using VHSR data: case of the coastal area of Benin, in: J. Krisp, L. Meng, R. Pail, U. Stilla (Eds.), Earth Observation of Global Changes (EOGC). Lecture Notes in Geoinformation and Cartography, Springer, Berlin, Heidelberg, 2013, https://doi.org/10.1007/978-3-642-32714-8 5.

[62] L.P. Assogba, Etude de la dynamique du trait de côte et des stratégies de gestion du risque d'érosion côtière : cas de Cotonou au Bénin de 1955 à 2018, Université de Liège, 2018, p. 47p.

[63] O. Teka, U. Sturm-Hentschel, J. Vogt, H.-P. Bähr, S. Hinz, B. Sinsin, Process analysis in the coastal zone of Benin through remote sensing and socio-economic surveys, Ocean Coast Manag. 67 (2012) 87-100, https://doi.org/10.1016/j. ocecoaman.2012.06.005.

[64] C. Lemée, M. Guillard, G. Fleury-Bahi, N. Krien, C. Chadenas, E. Chauveau, M. Desse, M. Coquet, M. Lamarre, O. Navarro, What meaning do individuals give to coastal risks? Contribution of the social representation theory, Mar. Pol. 108 (2019) 103629, https://doi.org/10.1016/j.marpol.2019.103629.

[65] P. Slovic, M.L. Finucane, E. Peters, D.G. MacGregor, Risk as analysis and risk as feelings: some thoughts about affect, reason, risk, and rationality, Risk Anal. 24 (2) (2004) 311-322, https://doi.org/10.1111/j.0272-4332.2004.00433.x.

[66] E. Michel-Guillou, C. Meur-Ferec, Representations of coastal risk (erosion and marine flooding) among inhabitants of at-risk municipalities, J. Risk Res. 49 (2016) 145-799, https://doi.org/10.1080/13669877.2015.1119181.

[67] O. Teka, J. Vogt, Social perception of natural risks by local residents in developing countries-The example of the coastal area of Benin, Soc. Sci. J. 47 (2010) 215-224, https://doi.org/10.1016/j.soscij.2009.07.005.

[68] J. Schumacher, G. Schernewski, M. Bielecka, M.I. Loizides, X.I. Loizidou, Methodologies to support coastal management - a stakeholder preference and planning tool and its application, Mar. Pol. 94 (2018) 150-157, https://doi.org/ 10.1016/j.marpol.2018.05.017.

[69] S. Ojeda, The Kampala convention on internally displaced persons: some international humanitarian law aspects, Refug. Surv. Q. 29 (2010) 58-66, https:// doi.org/10.1093/rsq/hdq028.

[72] A.M. Findlay, Migrant destinations in an era of environmental change, Global Environ. Change (2011) 21S50-21S58, https://doi.org/10.1016/j. gloenvcha.2011.09.004.

[73] B. Neumann, A.T. Vafeidis, J. Zimmermann, R.J. Nicholls, Future coastal population growth and exposure to sea-level rise and coastal flooding-a global assessment, PLoS one 100118571 (3) (2015), https://doi.org/10.1371/journal. pone.0118571.

[74] INSAE. Enquête Modulaire Intégrée sur les Conditions de Vie des Ménages (EMICoV) 2007: principaux indicateurs, Ministère de la prospective, du développement et de l'évaluation de l'action publique, 2009, p. 60.

[75] INSAE. Principaux indicateurs socio démographiques et économiques du département du Littoral (RGPH-4, 2013), Ministère du Plan et de Développement, 2016, p. 85. 